\title{
Assessment of air quality changes during COVID-19 partial lockdown in a Brazilian metropolis: from lockdown to economic opening of Rio de Janeiro, Brazil
}

\author{
Karmel Beringui ${ }^{1}$ - Elizanne P. S. Justo ${ }^{1}$ Anna De Falco ${ }^{1} \cdot$ Eduarda Santa-Helena $^{1} \cdot$ Werickson F. C. Rocha ${ }^{2}$. \\ Adrien Deroubaix ${ }^{3} \cdot$ Adriana Gioda $^{1}[$
}

Received: 9 August 2021 / Accepted: 2 November 2021 / Published online: 23 November 2021

(c) The Author(s), under exclusive licence to Springer Nature B.V. 2021

\begin{abstract}
During the COVID-19 pandemic, restrictive measures are taken by several cities around the world, as well as Rio de Janeiro, reducing routine activities in large urban centers and primary pollutant emissions. This study aims to assess air quality during this partial lockdown through $\mathrm{O}_{3}, \mathrm{CO}$, and $\mathrm{PM}_{10}$ concentrations and meteorological data collected in five air quality monitoring stations spread over the whole city, considering the substantial changes in city routine. The period evaluated starts in March 2020, when the partial lockdown was decreed, and ends in September 2020, when economic opening ended. Compared with 2019 data, CO concentration reduced significantly, as expected since the main source of these pollutants is vehicular traffic. $\mathrm{O}_{3}$ concentration increased, most probably as a consequence of the reduction in primary pollutants. On the other hand, $\mathrm{PM}_{10}$ concentration did not vary significantly. From June to September, pollutant concentrations increased responding to the economic opening. Thereby, the partial lockdown contributed to improving air quality in Rio de Janeiro City, which means that changes in work format may be an alternative to reduce atmospheric pollution in big cities, since home office contributes to mobility reductions, and consequently to vehicular emissions.
\end{abstract}

Highlights

- Lockdown contributed to $\mathrm{CO}$ reduction and $\mathrm{O}_{3}$ increase.

- Differences on rain profile explain low variation on $\mathrm{PM}_{10}$ concentrations.

- Lockdown has been like a very long weekend concerning atmospheric pollution.

- Home office and distance learning improve air quality.

Keywords Atmospheric pollution · Criteria pollutants · Lockdown

\section{Introduction}

The COVID-19 pandemic spread rapidly around the world in early 2020 after the first cases in Wuhan, Hubei province (China), in December 2019 (Saadat et al. 2020). On March 11, 2020, there were more than 118,000 cases in 114

Adriana Gioda

agioda@hotmail.com

1 Pontifical Catholic University of Rio de Janeiro, Rio de Janeiro, RJ 22451-900, Brazil

2 Quality and Technology (INMETRO), National Institute of Metrology, Duque de Caxias, RJ 25250-020, Brazil

3 Environmental Modeling Group, Max Planck Institute for Meteorology, Hamburg, Germany countries, and 4291 people had lost their lives. Therefore, WHO assessed that COVID-19 could be characterized as a pandemic (World Health Organization 2020). In Brazil, the first case of COVID-19 was registered on February 26 in São Paulo, while the first case in Rio de Janeiro was registered on March 5. A year later (February 26, 2021), there were more than 10 million confirmed cases in all regions of Brazil (Ministério da Saúde 2021); the majority of confirmed cases were in the southeastern region, Rio de Janeiro (RJ), with 206,149 confirmed cases (Prefeitura do Rio de Janeiro 2021).

The health risk posed by the novel coronavirus, in addition to its high transmissibility, made several cities in the world stop their activities in an attempt to contain the growing number of cases of the disease and deaths. The lockdown around the world changed the pollutant emission profile, 
inducing improvements in primary pollutants in several cities (Bao and Zhang 2020; Saadat et al. 2020; Gaubert et al. 2021). One of the main consequences of partial closure was the decrease in sources of air pollutants. This change in the city's routine can cause an improvement in air quality due to a decrease in the emission of pollutants (Nakada and Urban 2020). It is worth noting that if a region already has good air quality in a routine situation, quarantine will not have a significant impact on air quality (Zangari et al. 2020).

Cities as Milan, New York, New Delhi, and London recorded an improvement in air quality (Collivignarelli et al. 2020; Girdhar et al. 2020; Sarfraz et al. 2020). In China, an extremely high haze event was shown by Le et al. (2020), while $\mathrm{O}_{3}$ has increased in many megacities (Venter et al. 2020). Even in the most populated area in China, an improvement in air quality was observed, which was attributed to mobility reduction (Filonchyk and Peterson 2020). In Barcelona, there were reductions in $\mathrm{PM}_{10}$ and $\mathrm{NO}_{2}$ concentrations during the lockdown compared to the previous months (Tobías et al. 2020). Some South American countries (Colombia, Ecuador, Argentina, and Peru) also recorded an improvement in air quality due to social isolations; however, some authors predicted that pollution levels would return to normal following the return of economic activities (BolañoOrtiz et al. 2020; Zambrano-Monserrate and Ruano 2020; Camargo-Caicedo et al. 2021; Rojas et al. 2021).

Brazil declared COVID-19 a public health emergency on March 3 (Croda et al., 2020). From that, Brazilian cities began to take restrictive measures to contain the progress of the disease and decreed partial lockdown (Dantas et al. 2020; Nakada and Urban 2020). In Rio de Janeiro State, the governor declared a public health emergency on March 16, stating that educational institutions, cultural establishments, and restaurants be closed. Subsequently (March 21), access to the city of Rio de Janeiro was limited by prohibiting the entry of public transport from other cities. Besides that, industries, commercial establishments, and airports have reduced their operations (Crokidakis 2020). From July 1, the city of Rio de Janeiro started gradual opening of economic activities, which was planned to take place in six stages, which ends on September 1.

Some studies regarding Brazil's air quality assessments and pandemic have been published. In São Paulo, there was an improvement in air quality related to the $\mathrm{PM}_{10}$, $\mathrm{PM}_{2.5}$, and $\mathrm{NO}_{2}$ concentrations, with significant drops of $45 \%, 46 \%$, and 58\%, respectively (Debone et al. 2020). Nakada and Urban 2020) evaluated the variations in pollutant concentrations during the lockdown at four sites in São Paulo City. Overall, there were drastic reductions in the concentrations of $\mathrm{NO}(77 \%), \mathrm{NO}_{2}(54 \%)$, and $\mathrm{CO}$ (65\%) compared to the 5-year monthly average. As in other megacities (Venter et al. 2020), in São Paulo, there was also an increase in $\mathrm{O}_{3}$ concentrations (30\%) (Nakada and Urban 2020). In three stations in Rio de Janeiro (Bangu, Irajá, and Tijuca), CO levels showed significant reductions (30-48\%), followed by $\mathrm{NO}_{2}$, while $\mathrm{PM}_{10}$ levels only decreased in the first week of lockdown. Ozone concentrations have also increased in Rio de Janeiro City (Dantas et al. 2020). Pollutants directly related to vehicles, like $\mathrm{CO}$ and $\mathrm{NO}_{2}$, showed the highest reduction. According to Siciliano et al. (2020), in Rio de Janeiro, their reduction was about $10-40 \%$. Satellite data obtained for southeastern Brazilian cities also show pollutants decrease. In May 2020, a reduction of $42 \%$ in $\mathrm{NO}_{2}$ was recorded in São Paulo in comparison with the monthly average obtained between 2015 and 2019. Rio de Janeiro records a decrease even higher, 49.6\% (Brandao and Foroutan 2021).

Social isolation measures adopted to contain the spread of coronavirus transformed one of the major Brazilian metropolises into a real laboratory where air pollution could be studied considering changes in political restrictions. Since the concentrations of pollutants vary between different areas of the same city, the results may not show the same reductions. The main goal of this work is to evaluate air quality changes in five air quality monitoring stations from Rio de Janeiro City, through the concentrations of $\mathrm{O}_{3}, \mathrm{CO}$, and $\mathrm{PM}_{10}$ between March and September 2020, making a comparison with the concentrations observed in the same period of 2019 and considering the meteorology influence. Although some studies have been conducted in Rio de Janeiro, they focused on the primary effects of the partial lockdown on air quality, considering from the first weeks to the third month of social isolation. This study evaluated pollutant concentrations considering changes in political restriction since the lockdown proclamation until economic opening, and besides that estimate meteorological conditions and urban source emission contribution.

\section{Materials and methods}

\section{Study area}

Rio de Janeiro is a coastal city with an estimated population of more than 6.7 million inhabitants and more than $75 \%$ of its territory is urbanized (IBGE 2020). One of the main sources of pollution in the city is vehicle traffic, as it has a fleet of more than 2.5 million cars, including light vehicles, motorcycles, cargo vehicles, and municipal transport buses (Detran 2020). In this study, five air quality monitoring stations will be considered. Copacabana, located in the southern zone, Tijuca, in the northern, Bangu and Campo Grande 
in the western zone, and Centro, located in the central region of the city. Figure 1 presents the location of monitoring stations and Table 1 presents characteristics of neighborhoods where monitoring stations are located.

\section{Air quality and meteorological data}

Data of regulated pollutant concentrations were made available online by the Municipal Environment Department of Rio de Janeiro City. For this study, the concentrations of $\mathrm{PM}_{10}$ $\left(\mu \mathrm{g} \mathrm{m}^{-3}\right), \mathrm{CO}(\mathrm{ppm})$, and $\mathrm{O}_{3}\left(\mu \mathrm{g} \mathrm{m}^{-3}\right)$ obtained at five air

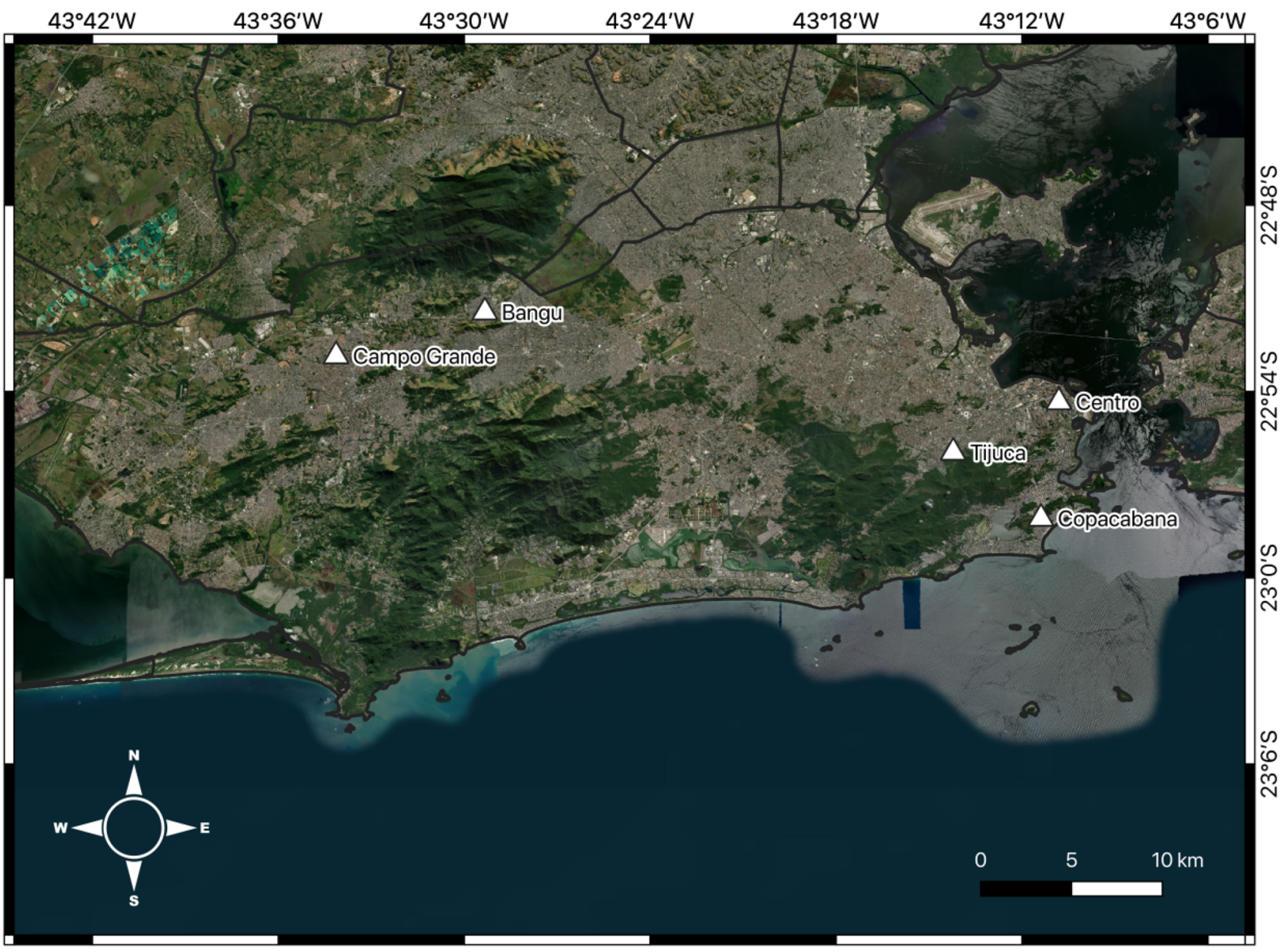

Fig. 1 Rio de Janeiro City map with air quality monitoring stations highlighted. Black line indicates city boundaries

Table 1 Sampling station descriptions

\begin{tabular}{|c|c|c|}
\hline Station & Pollutants & Surrounding characteristics \\
\hline Bangu & $\mathrm{CO}, \mathrm{O}_{3}$, and $\mathrm{PM}_{10}$ & $\begin{array}{l}\text { Lowland areas and land with slopes that exceed } 500 \mathrm{~m} \text {. The occupation of the soil is with residences, forest, } \\
\text { and mineral exploration areas. Located near Brazil Avenue, an important road that crosses the city }\end{array}$ \\
\hline Campo Grande & $\mathrm{CO}, \mathrm{O}_{3}$, and $\mathrm{PM}_{10}$ & $\begin{array}{l}\text { Land with elevations up to } 200 \mathrm{~m} \text {. It is predominantly occupied by residential and commercial buildings, } \\
\text { but it also has areas of vegetation, industrial enterprises, and rural activity }\end{array}$ \\
\hline Centro & $\mathrm{CO}, \mathrm{O}_{3}$, and $\mathrm{PM}_{10}$ & $\begin{array}{l}\text { Lowlands and part of Guanabara Bay. Hills with a slope of up to } 100 \mathrm{~m} \text { and land occupation with build- } \\
\text { ings that shelter the financial and commercial center of the city. Near streets with intense vehicle flux and } \\
\text { under influence of Brazil Avenue }\end{array}$ \\
\hline Copacabana & $\mathrm{CO}, \mathrm{O}_{3}$, and $\mathrm{PM}_{10}$ & $\begin{array}{l}\text { Beach and hills with slopes of } 100 \text { to } 400 \mathrm{~m} \text {. High population density that occupies high-altitude buildings. } \\
\text { Intense vehicle traffic on main streets, including public transport buses }\end{array}$ \\
\hline Tijuca & $\mathrm{CO}, \mathrm{O}_{3}$, and $\mathrm{PM}_{10}$ & $\begin{array}{l}\text { Flat land and hills with a slope of up to } 500 \mathrm{~m} \text {. The occupation of the soil is with residence, predominantly } \\
\text { of buildings, and forest areas. Intense traffic on streets, mainly in the morning and in the evening }\end{array}$ \\
\hline
\end{tabular}


quality monitoring stations between March and September for the years 2019 and 2020 will be considered. Pollutants are sampled following the standard methodology established by Brazilian law (CONAMA, 2018; MMA, 2019).

The configuration of the SMAC air quality monitoring network detects $\mathrm{CO}$ by non-dispersive infrared (NDIR) spectrophotometry technology using an EC 9830 Serinus 30 series; $\mathrm{O}_{3}$ by non-dispersive ultraviolet (UV) absorption technology through EC 9810 Serinus 10 series; and $\mathrm{PM}_{10}$ by $\beta$-ray attenuation through Met One BAM 1020. Data for $\mathrm{CO}$ and $\mathrm{O}_{3}$ were obtained at 10 -min intervals, while $\mathrm{PM}_{10}$ at 1 -h intervals. They were organized on a sheet as a continuous hourly average after evaluation of anomalous values. Equipment has been calibrated periodically according to manufacturer's instructions.

To assist in the interpretation of the atmospheric pollution data, the meteorological variables (wind speed (WS), wind direction (WD), pressure (P), solar radiation (SR), rainfall $(\mathrm{RF})$, temperature $(\mathrm{T})$, and relative humidity $(\mathrm{RH})$ ) measured in each of the monitoring stations will be considered.

Online hourly data for each pollutant and meteorological parameters from SMAC (from Portuguese, Secretaria Municipal do Meio Ambiente) were used. The data were organized into daily, hourly, and monthly averages. It also evaluated pollutant concentrations over weekdays.

Satellite data from Giovanni have been obtained for aerosol throughout the "Combined Dark Target and Deep Blue AOD at 0.55 micron for land and ocean" dataset and CO "Multispectral CO Surface Mixing Ratio (Daytime/Descending)." A time average map (March 2020 - September 2020) was plotted to evaluate pollutant trends and transportation. For this analysis, the period considered was divided into three short periods according to pollutant variation measured by surface data: March-April (strict lockdown), May-June (social isolation relaxation), and July-September (economic opening).

Pollutant's concentration variation was evaluated considering changes in routine activities in Rio de Janeiro City after the lockdown and opening decrees. A timeline with the main measures taken by the government of Rio de Janeiro State is presented in Fig. 2, and the opening stages adopted by the city hall of Rio de Janeiro City are presented in Fig. 3.

\section{Mobility data}

According to Chapin and Roy (2021), one of the effects of COVID-19 was mobility reduction. Using mobility data provided by Apple, they built an application to show mobility variation and confirmed cases of COVID-19 which could be used by researchers to evaluate pandemic effects. While their application is limited to local regions, a similar evaluation may be done with the Apple database.

Mobility data provided by Apple (https://covid19.apple. com/mobility) and Google (https://www.google.com/covid 19/mobility/) companies, available online since the beginning of the pandemic, were used as an indication of emission changes. Apple provided data since January 13, while Google since February 15. Both datasets were evaluated until September 30. Apple dataset considers that the first day presents $100 \%$ of mobility and the following days are a variation from it. Google mobility dataset represents the variation in mobility compared to the first day.
Fig. 2 Timeline with main measures taken by Rio de Janeiro State government to control the spread of coronavirus and easing measures after the number of cases starts to decrease
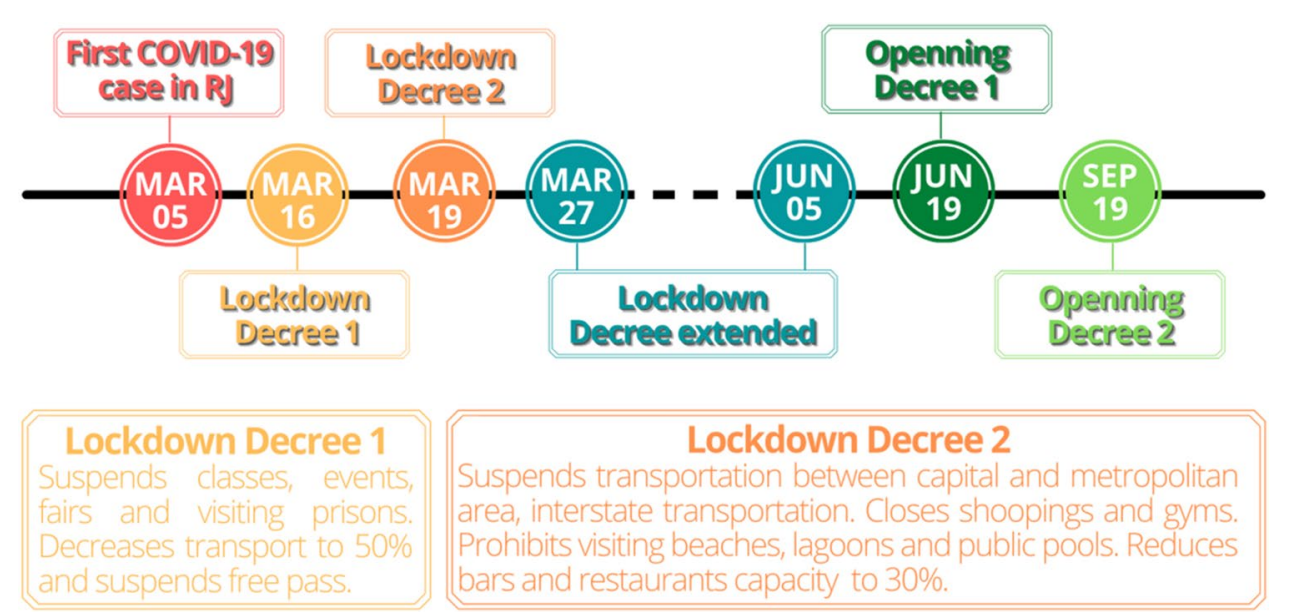

\section{Opening Decree 1}

Outdoor and drive-in activities. Tourist points with $50 \%$ of capacity. Sporting events without the audience. Bars and restaurants with $50 \%$ of capacity. Shopping between 12-20h. Religious events. Return of intercity and interstate transport.

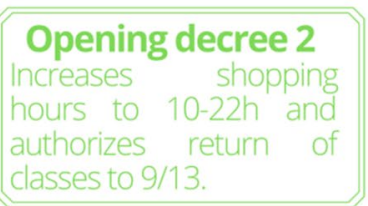


Fig. 3 Timeline with opening stages adopted by the city hall of Rio de Janeiro City

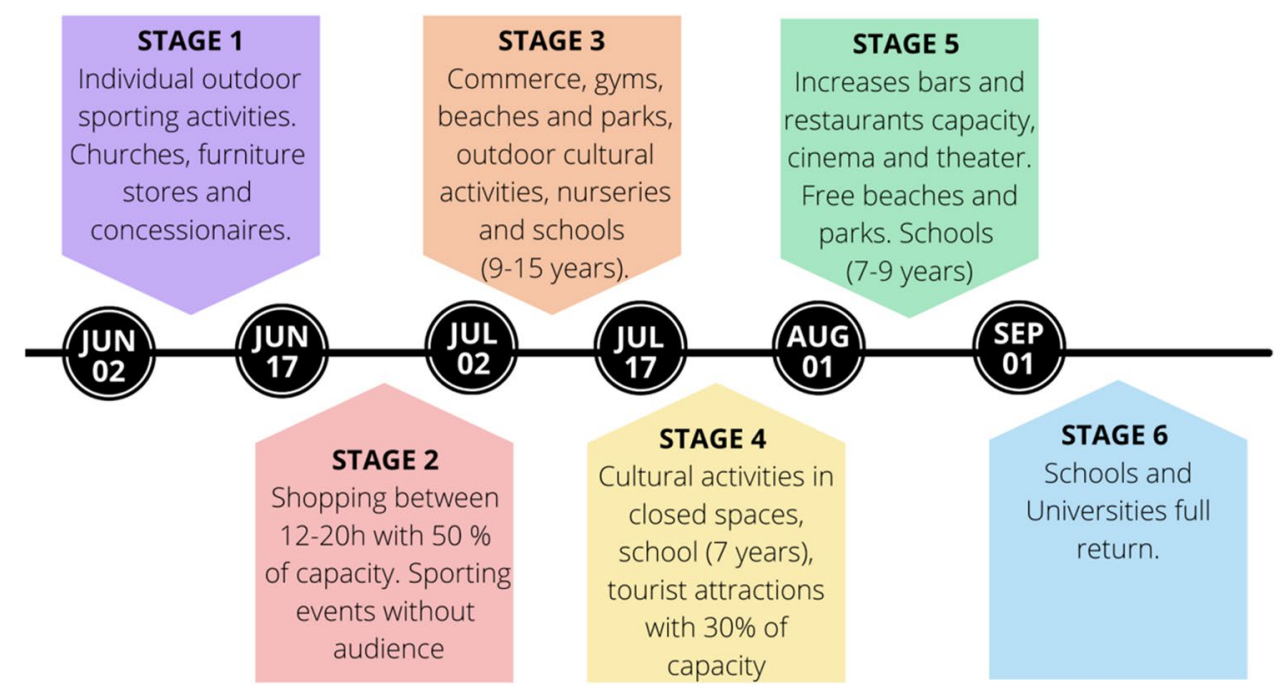

For comparison proposes, average data was considered for all of Brazil, Rio de Janeiro State, and Rio de Janeiro City, the focus of this study.

\section{Data analysis}

The software R throughout R Studio was used for data analysis. The Openair package was employed to make pollutant and mobility time variation plots, the ggplot2 package to make kernel density analysis, and ggcorrplot to make correlation matrices. The Shapiro-Wilk test was applied to test data normality and the WilcoxonMann-Whitney test to compare months from 2020 and 2019.

\section{Results}

\section{Mobility profile}

The main air pollutant source in urban centers is vehicle emission; thus, changes on mobility are an indication of emission variation. According to mobility data provided by Apple and Google (Figure S1 - online resource), mobility changes in Rio de Janeiro State, Rio de Janeiro City, and Brazil presented the same profile. Both datasets indicate that mobility reduction started in mid-March, reaching around $90 \%$ of decrease at the end of April. It indicates that social isolation measures caused a reduction on emission sources, once mobility decreased after the lockdown decree.

Although the economic opening at the city occurred only from June, since May people relaxed social isolation by themselves and started to return to some activities. The return of public transportation allowed by the state government has contributed to the increase in the number of people on the streets.

\section{Pollutant concentration distribution}

Considering the daily average concentration in 2019 and 2020 over the same period, for the whole period of 2019, the daily average concentration and standard deviation of $\mathrm{CO}$ was $0.32 \pm 0.27 \mathrm{ppm}, \mathrm{O}_{3}$ was $31 \pm 26 \mu \mathrm{g} \mathrm{m}^{-3}$, and $\mathrm{PM}_{10}$ was $38 \pm 24 \mu \mathrm{g} \mathrm{m}^{-3}$. In 2020, the average concentration and standard deviation of $\mathrm{CO}$ was $0.23 \pm 0.20 \mathrm{ppm}, \mathrm{O}_{3}$ was $38 \pm 27 \mu \mathrm{g} \mathrm{m}^{-3}$, and $\mathrm{PM}_{10}$ was $36 \pm 23 \mu \mathrm{g} \mathrm{m}^{-3}$. Figure 4 shows the difference between daily concentration in 2020 and the averaged concentration in 2019 of three gases. This difference represents an anomaly caused by COVID-19 (i.e., the daily concentration in 2020 minus the averaged concentration in 2019).

As expected, daily CO concentrations were lower in 2020. CO concentrations decreased quickly on 22 March (of 0.10 to $0.15 \mathrm{ppm}$, compared to early March). During this week (the second week of the lockdown), the entrance of public transport in Rio de Janeiro City was prohibited. The reduction in the vehicle traffic in the city consequently causes a decrease in the emission of CO. The anomaly of CO concentrations compared to the average on this period in 2019 remains important until the end of May.

For $\mathrm{O}_{3}$, the anomalies are mostly positive (ranging between -5 and +20 ), except for one station (Bangu) presenting a different behavior. As observed in other cities (Venter et al. 2020), the $\mathrm{O}_{3}$ concentration in 2020 was higher in all monitoring stations. The tropospheric $\mathrm{O}_{3}$ chemistry is complex; primary pollutants participate both in its formation and 
Fig. 4 Difference between daily concentration in 2020 and the averaged concentration in 2019 of three pollutants for the same period (the black line is the mean of all stations and the blue lines are concentration at each station)

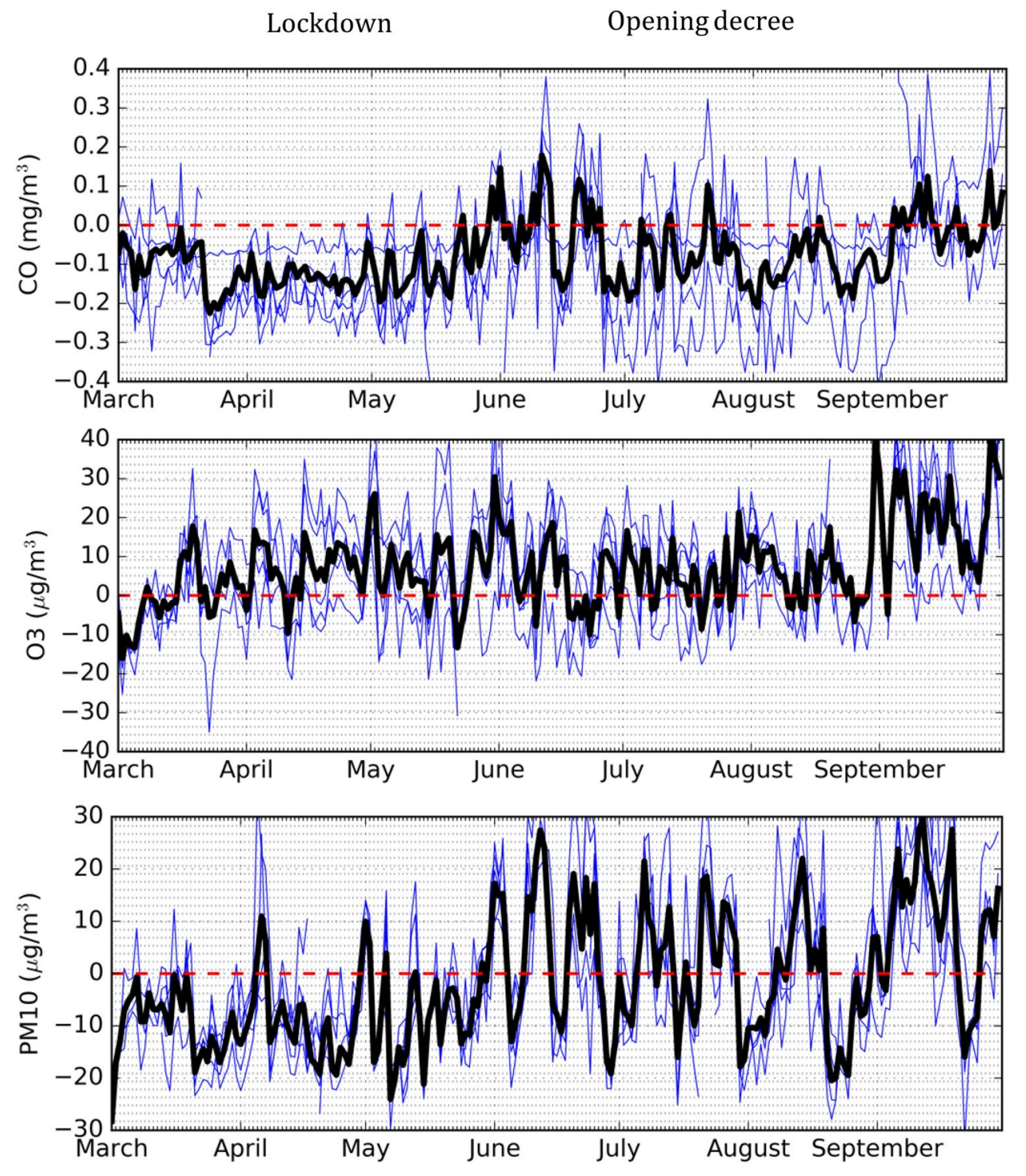

depletion. According to Geraldino et al. (2017), the topography and meteorology of Rio de Janeiro City favor $\mathrm{O}_{3}$ formation, and its photochemistry is limited by volatile organic compounds (VOCs). In this case, low $\mathrm{NO}_{2}$ concentration, as a result of low $\mathrm{NO}$ concentration, leads to high $\mathrm{O}_{3}$ concentration. It is explained by the reaction $\mathrm{NO}+\mathrm{O}_{3}$ accountable for $\mathrm{O}_{3}$ depletion (Geraldino et al. 2017, 2020). Thus, because a decrease in $\mathrm{NO}_{2}$ concentration is a direct result of a reduction in $\mathrm{NO}$ concentration, higher $\mathrm{O}_{3}$ concentration may be attributed to lower NOx concentration indicated by low $\mathrm{NO}_{2}$ concentration. This same relation was verified during the lockdown in other countries around the world. Dantas et al. (2020) reported a reduction (32-54\%) in $\mathrm{NO}_{2}$ concentration in Rio de Janeiro City for the last week of March 2020 which was attributed to the reduction in car flow by $80 \%$.

There were two high $\mathrm{O}_{3}$ events on 1 and 31 May observed at all monitoring stations. Meteorological parameters that might enhance $\mathrm{O}_{3}$ concentration do not explain these events. To explain them, data for $\mathrm{NO}, \mathrm{NO}_{2}$, and $\mathrm{NOx}$ concentration, which were provided only for the Bangu station, were evaluated. The high $\mathrm{O}_{3}$ events coincide with days on which the lowest NOx concentrations were recorded. As pollutant concentration profiles were similar for all stations, it is possible to infer that lower nitrogen oxide concentrations were also recorded those days. Once those gases participate in $\mathrm{O}_{3}$ decomposition, higher $\mathrm{O}_{3}$ concentration is observed when they are at reduced levels. As mentioned above, $\mathrm{O}_{3}$ photochemistry is VOC limited; thus, its concentration is enhanced by low NOx levels and high temperatures.

$\mathrm{PM}_{10}$ anomaly is negative during the Rio de Janeiro lockdown, mostly ranging between 0 and -15 , which was expected for $\mathrm{CO}$ concentration. The main $\mathrm{PM}_{10}$ source in urban areas is vehicle traffic (Miranda et al. 2012; Ali et al. 2019). Then, the huge traffic reduction after lockdown 
measures, corroborated by the mobility decrease of around $90 \%$, can be considered the main reason for the decrease in $\mathrm{PM}_{10}$ concentration. In June, when the lockdown easing measures started, anomalies became positive, showing that $\mathrm{PM}_{10}$ concentration increased, reaching values even higher than those in 2019.

To assist in data interpretation, Spearman correlations (Figure S2 - Online Resource) were calculated to verify the relation between pollutants. It was noticed in Fig. 4 that the two high ozone events correspond to two $\mathrm{PM}_{10}$ positive anomalies (peak on the $\mathrm{PM}_{10}$ time series) reaching +15 . However, the Spearman correlation $(p<0.05)$ obtained between these pollutants was positive but weak $(r<0.40)$ at all monitoring stations during May 2020. On May 1 and 31 , when occurring in high ozone events, the correlations between them were weekly negative. According to Nishanth et al. (2014), the relation between $\mathrm{PM}_{10}$ and $\mathrm{O}_{3}$ depends on particle absorption characteristics. The large particles' surface area can contribute to heterogeneous reactions involving the tropospheric ozone. Particles that absorb radiation can contribute to an increase in the concentration of $\mathrm{O}_{3}$, whereas particles that disperse light contribute to a decrease in the concentration of $\mathrm{O}_{3}$ in the atmosphere.

In all monitoring stations, moderate positive correlations were observed between $\mathrm{O}_{3}$ and $\mathrm{PM}_{10}$. These positive correlations are related to the anthropogenic origin of these pollutants. In the Centro station, there was a correlation between $\mathrm{O}_{3}$ and $\mathrm{PM}_{10}$ in all the months of 2020, and in the Tijuca station, correlations were observed in all the evaluated months, the largest of them observed in May and June, both in 2019 and in 2020.

A descriptive statistic of meteorological variables is presented in Table S1 (Online Resource). Comparing both years, it is possible to notice that Rio de Janeiro City was under the same meteorological conditions. However, it is possible to highlight rainfall and wind speed at Tijuca in 2020 were higher than those in 2019. The rainfall was influenced by volume recorded in May, which was more than 5 times higher than that of other months. The wind speed was about 3 times higher than the mean value of 2019, mainly from winds that come from west and northwest, where the Tijuca National Forest is located. These wind results were influenced by values recorded in March 2020. Although Tijuca presented these meteorological singularities in March and May, rainfall and wind speed do not explain pollutant variation. As in most months, meteorological parameters did not change; they could not be accountable for air quality variation during the period evaluated.

Positive Spearman correlations $(p<0.05)$ were observed in Bangu, Campo Grande, and Centro, from moderate to strong, between the $\mathrm{O}_{3}$ concentrations and SR, T, and WS. It was also found to have negative correlations between $\mathrm{O}_{3}$ and $\mathrm{RH}$ of the air. These correlations were already expected since the tropospheric $\mathrm{O}_{3}$ is formed by photochemical processes; therefore, a greater solar radiation favors its formation, and besides it also contributes to the increase in temperature (Gioda et al. 2018; De La Cruz et al. 2019; Geraldino et al. 2020). The correlation with WS indicates that pollutants from other regions are participating in the $\mathrm{O}_{3}$ formation processes. Higher RH of the air makes it harder for the sun to arrive, disfavoring $\mathrm{O}_{3}$ formation.

In Bangu, Campo Grande, and Centro, moderate negative correlations between $\mathrm{O}_{3}$ and $\mathrm{CO}$ were also observed. In Bangu, such correlations were observed only in 2019 (March and June). In Campo Grande, they were observed in May and June of both years evaluated. In Centro, they were observed mainly in 2020 . As $\mathrm{O}_{3}$ is a secondary pollutant, explaining its concentration should consider several variables, as mentioned above. Carbon monoxide concentration exerts, mainly, an indirect effect on $\mathrm{O}_{3}$ concentrations. Negative correlations between them may indicate $\mathrm{O}_{3}$ depletion through photochemical reaction with $\mathrm{NOx}$, since NOx and CO may present the same source, then $\mathrm{O}_{3}$ decomposition is favored in polluted conditions. Another explanation is the hydrocarbon oxidation by $\mathrm{O}_{3}$ molecules, which reduces $\mathrm{O}_{3}$ concentration and increases $\mathrm{CO}$ concentration. And finally, the stratospheric $\mathrm{O}_{3}$ intrusion in the troposphere may increase $\mathrm{O}_{3}$ concentration while $\mathrm{CO}$ decreases, once this air is richer in $\mathrm{O}_{3}$ (Voulgarakis et al. 2011). Since $\mathrm{O}_{3}$ chemistry in Rio de Janeiro City is limited by VOC, low NOx concentrations lead to high $\mathrm{O}_{3}$ concentrations. Considering that the main source of $\mathrm{CO}$ and $\mathrm{NOx}$, which includes $\mathrm{NO}_{2}$, is fuel combustion, the reduction of mobility after the lockdown decree implies a decrease in $\mathrm{CO}$ and NOx emission. Thus, the negative correlation $\mathrm{O}_{3} \times \mathrm{CO}$ does not present a cause-and-effect relationship; nevertheless, it represents a consequence of the negative correlation between $\mathrm{O}_{3}$ and $\mathrm{NO}_{2}$ once $\mathrm{CO}$ and $\mathrm{NO}_{2}$ come from the same source.

Except for Copacabana, all monitoring stations presented moderate to strong correlations between $\mathrm{PM}_{10}$ and $\mathrm{CO}$, mainly from June to September. These results show that both pollutants may present the same emission source, which could be vehicular emissions. The lack of correlation in Copacabana indicates that the main source of $\mathrm{PM}_{10}$ is sea spray.

Moderate positive correlations between $\mathrm{PM}_{10}$ and temperature were also observed in Bangu, Copacabana, and Tijuca; these pollutants correlated in most of the evaluated months, except for June 2020 in Bangu and April 2020 in Tijuca. In general, $\mathrm{PM}_{10}$ and temperature present a negative correlation because high temperatures favor particle dispersion, which contributes to a decrease in $\mathrm{PM}_{10}$ concentration (Li et al. 2015). The positive correlations found in this study indicate that several other variables are influencing $\mathrm{PM}_{10}$ concentration that is accompanied by high temperatures (Kim 2019).

Considering that the lockdown period was between March 19 and June 19, which coincide with the second lockdown 
decree and first opening decree, considerable pollutant variation was observed, in comparison with the previous year. $\mathrm{CO}$ concentration reduced 21-62\%. $\mathrm{O}_{3}$ increased $15-74 \%$ except for that in Bangu where it decreased $11 \%$. $\mathrm{PM}_{10}$ decreased 5-22\% except for that Bangu where it increased 9\%.

\section{Air pollutant time variation}

Pollutant concentration averages obtained between March and September of 2019 and 2020 for all monitoring stations are presented in Figs. 5, 6, and 7 split by hour per weekday, hour, month, and weekday. Tables S2-S4 (Online Resource) present descriptive statistic data for all monitoring stations. Table 2 presents the percentage of monthly variation of each pollutant at all monitoring stations in 2020 in comparison with that in 2019. Negative values indicate lower concentrations recorded in 2020 .

To evaluate pollutant concentration variation, it was investigated if there is a statistically significant difference in the concentration levels of the components $\mathrm{CO}, \mathrm{O}_{3}$, and $\mathrm{PM}_{10}$ between the years 2019 and 2020. Due to the nonnormality of the data, the Wilcoxon-Mann-Whitney nonparametric test was applied with a significance level of 5\%. In other words, we sought to verify whether there was a change in concentration from 1 year to another considering it as a single period from March to September (Fig. 8). The comparison of each month from the 2 years is presented in Table 3, which shows the pairs of months that did not present statistical differences.

In general, the Copacabana station registered the lowest $\mathrm{CO}$ emission and the highest amount of $\mathrm{PM}_{10}$ when compared to the other stations. In Bangu, there was a reduction in CO emissions in 2020 when compared to 2019. An increase of $\mathrm{O}_{3}$ is observed in Tijuca, Copacabana, and Centro in 2020 when compared to 2019.

Considering the whole period, it can be seen that there was no change in the concentration of $\mathrm{O}_{3}$ in Bangu [ $p$-value 0.9268] and $\mathrm{PM}_{10}$ in Copacabana [ $p$-value 0.3532] in the period from March to September 2020 when compared to the same 2019 period.

\section{Carbon monoxide monthly concentration}

All stations are located close to high-traffic routes; therefore, the concentrations of the three pollutants studied were affected. The average monthly concentration and standard deviation of $\mathrm{CO}$ ranged from $0.04 \pm 0.04 \mathrm{ppm}$ in Copacabana to $0.5 \pm 0.2 \mathrm{ppm}$ in Campo Grande in 2020, while in 2019 the concentrations and
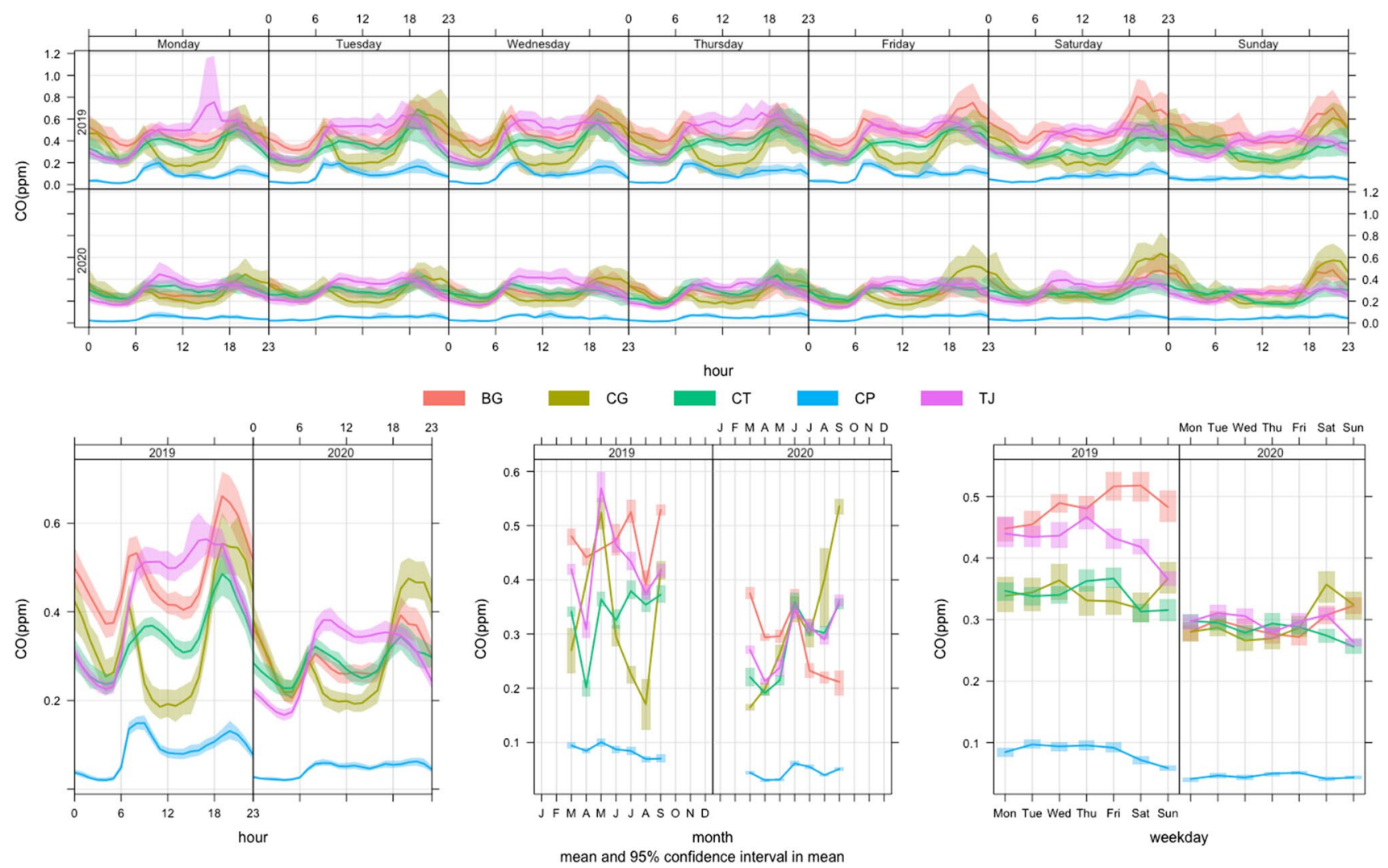

Fig. 5 Time variation of the concentrations of CO (ppm) at Bangu (BG), Campo Grande (CG), Centro (CT), Copacabana (CP), and Tijuca (TJ) stations in 2019 and 2020 

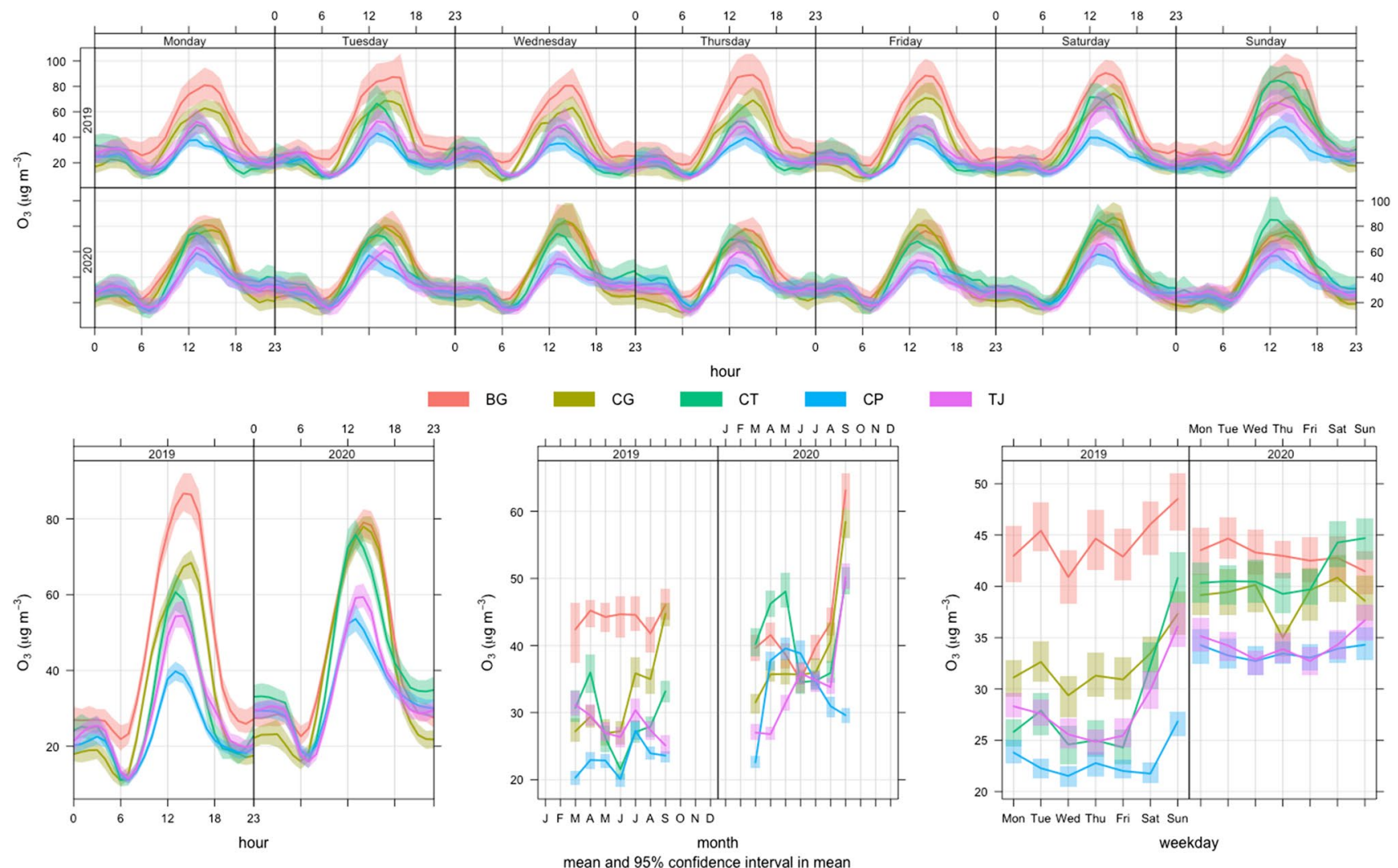

Fig. 6 Time variation of the concentrations of $\mathrm{O} 3(\mu \mathrm{g} \mathrm{m}-3)$ at Bangu (BG), Campo Grande (CG), Centro (CT), Copacabana (CP), and Tijuca (TJ) stations in 2019 and 2020

standard deviation ranged from $0.07 \pm 0.1 \mathrm{ppm}$ in Copacabana to $0.6 \pm 0.4 \mathrm{ppm}$ in Tijuca. However, no station exceeded the air quality standard established for $\mathrm{CO}$ by Brazilian legislation (9 ppm, 8-h mobile mean) (CONAMA 2018). The average concentration in 2020 is $97 \%$ below the Brazilian standard, while in 2019 it was $96 \%$ lower.

For most monitoring sites, monthly $\mathrm{CO}$ concentration obtained during 2019 presented higher values, with the exception of Campo Grande; in other words, CO reduction was verified during lockdown. This neighborhood is characterized by a strong presence of commercial enterprises. Besides that, in the surroundings of this region, some industrial enterprises are installed. It is observed that the first peak of concentration in 2020 occurs in June, when the restriction measures began to be reduced, and the second peak in September, when the last phase of the economic opening began. This neighborhood has one of the highest population densities, so the return of economic activities represents a greater number of people back on the streets compared to other neighborhoods in the city.

Statistically, CO concentration obtained in 2020, for most months, at all monitoring stations presented difference in relation to the previous year. The lower concentration obtained in 2020 is related to the reduction in vehicle flow, corroborated by mobility data, which had the contribution of the decrease up to $50 \%$ in public transport fleet and adoption of home office services by most part of companies.

The levels of CO in Copacabana decreased $31 \%$ in April 2020, in relation to March 2020. In comparison with concentration obtained in 2019, Copacabana also presented the greatest $\mathrm{CO}$ concentration reduction: 63\% in April and 68\% in March. Bangu, the site with the highest CO average concentrations in 2019, presented reductions between 22 and $60 \%$ in 2020 , compared to monthly CO average concentration with the previous year.

Considering $\mathrm{CO}$ concentration variation between March and September 2020, with the exception of Bangu, in all other stations increasing concentrations were observed from June. Although CO concentrations over the period evaluated presented an increase between 27 and $225 \%$ in relation to $\mathrm{CO}$ concentration registered in March 2020, they were, in most cases, below the values registered in the same months of 2019. Only Copacabana (June) and Centro (September) presented average concentrations with no statistical difference in relation to 2019 after opening decrees. The economic opening since June contributed to the increase in CO concentration; 

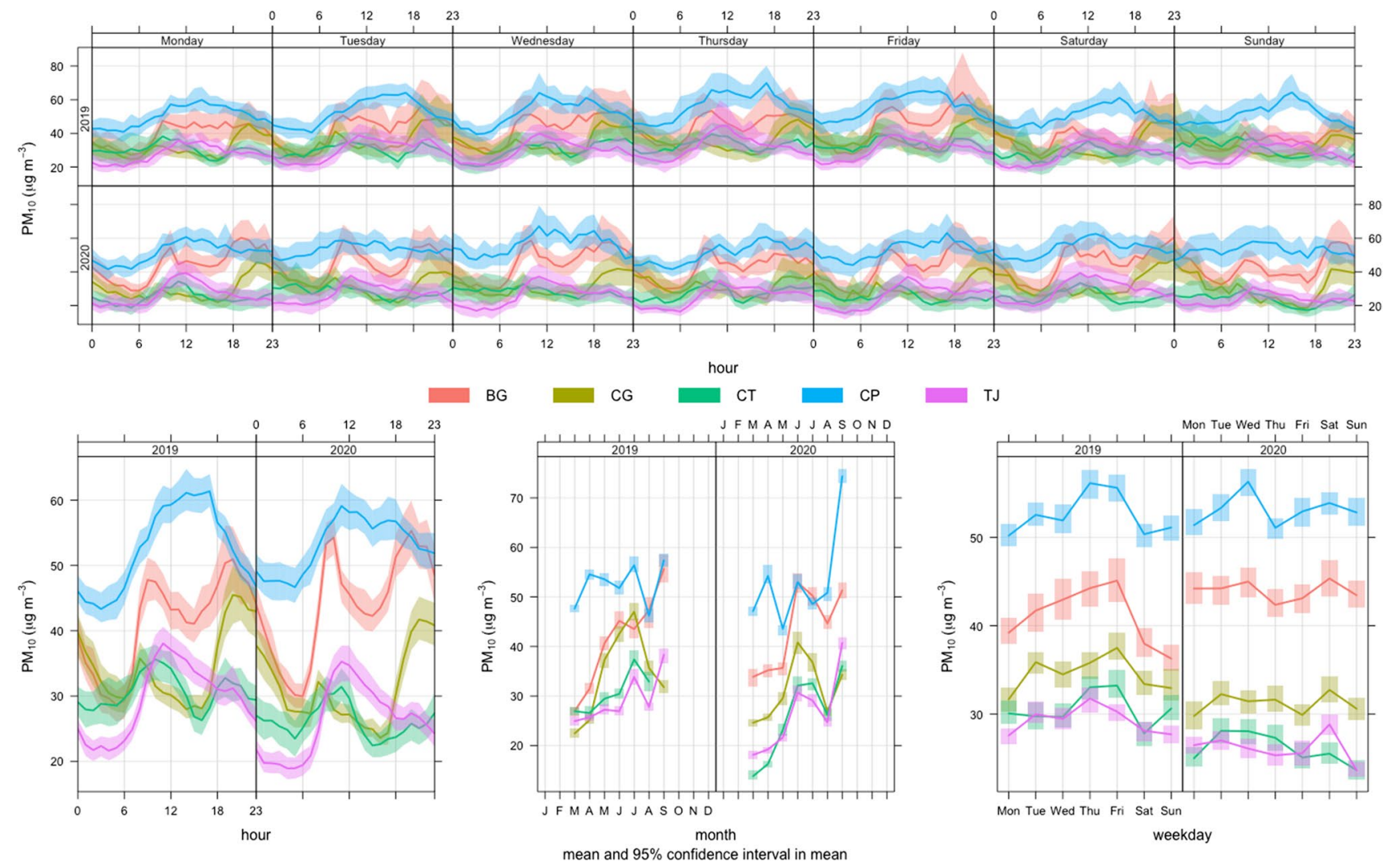

Fig. 7 Time variation of the concentrations of PM10 ( $\mu \mathrm{g} \mathrm{m-3)}$ at Bangu (BG), Campo Grande (CG), Centro (CT), Copacabana (CP), and Tijuca (TJ) stations in 2019 and 2020

Table 2 Variations in monthly concentrations of pollutants, expressed as percentage, comparing 2019 and 2020

\begin{tabular}{llllllll}
\hline Station & March & April & May & June & July & August & September \\
\hline Ozone variation (\%) & & & & & & & \\
Bangu & -7 & -8 & -13 & -22 & -11 & 4 & 37 \\
Campo Grande & 16 & 21 & 33 & 31 & 0 & 16 & 31 \\
Centro & 11 & 65 & 73 & 93 & 27 & 29 & 25 \\
Copacabana & 31 & 28 & 83 & 60 & 28 & 29 & 49 \\
Tijuca & -13 & -9 & 17 & 36 & 15 & 23 & 100 \\
Carbon monoxide variation (\%) & & & & & & \\
Bangu & -22 & -33 & $-*$ & -24 & -56 & -44 & -60 \\
Campo Grande & -39 & $-*$ & -50 & 17 & 32 & 135 & 28 \\
Centro & -53 & -64 & -69 & -30 & -35 & -43 & -27 \\
Copacabana & -35 & -5 & -41 & 10 & -18 & -15 & -5 \\
Tijuca & -35 & -31 & -58 & -26 & -28 & -22 & -13 \\
Particulate matter & $(<10 \mu \mathrm{m})$ & variation $(\%)$ & & & & & \\
Bangu & 26 & 12 & -12 & 17 & 15 & -6 & -8 \\
Campo Grande & 10 & 2 & -21 & -4 & -22 & -25 & 8 \\
Centro & -1 & -1 & -19 & 2 & -14 & 10 & 30 \\
Copacabana & -49 & -39 & -21 & 5 & -13 & -20 & $-*$ \\
Tijuca & -27 & -25 & -21 & 14 & -14 & -11 & 6 \\
\hline
\end{tabular}

*There was no data from this month in 2019 or 2020. 
Fig. $8 \mathrm{CO}, \mathrm{O} 3$, and PM10 data distribution for the period between March and September of 2019 and 2020
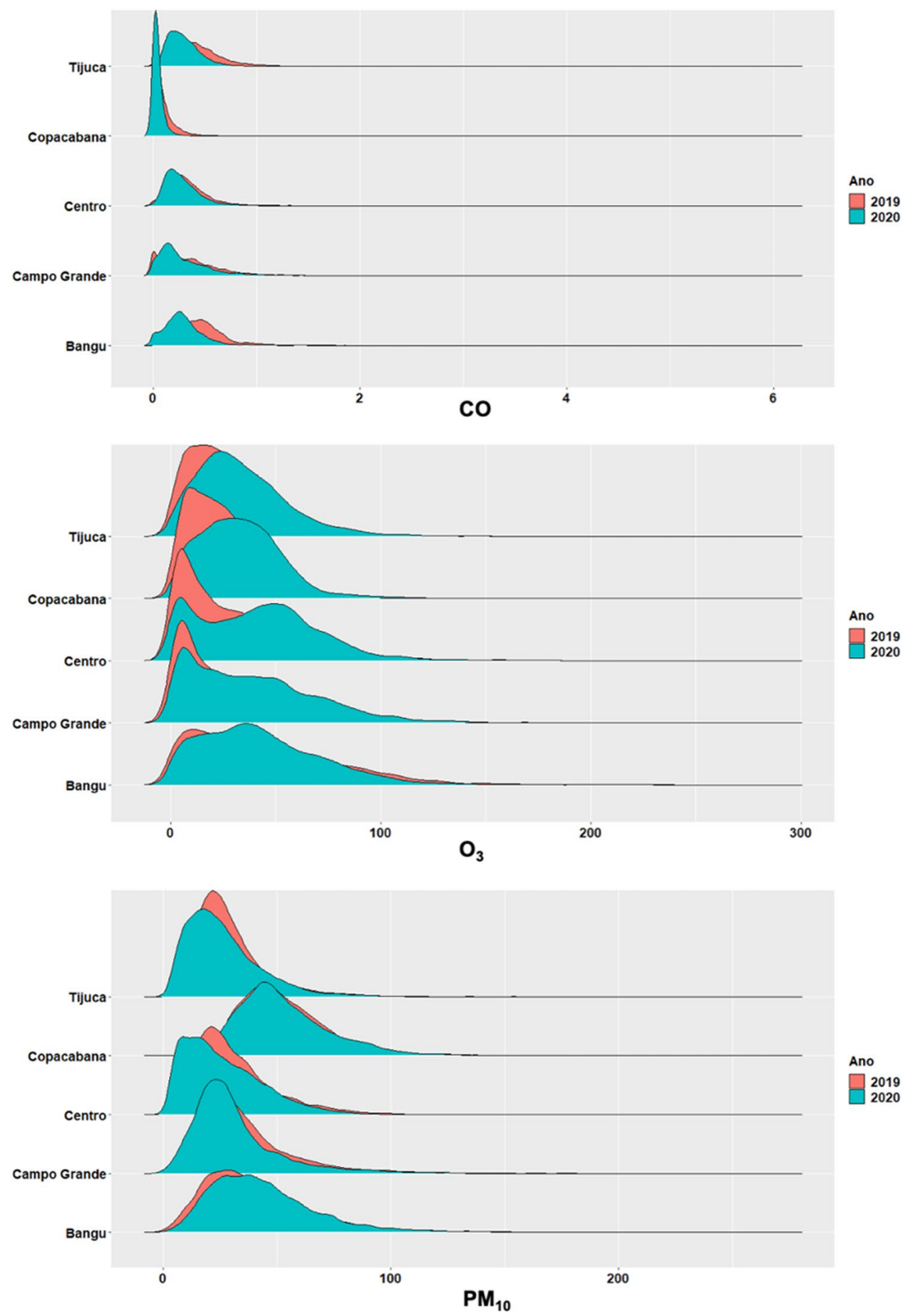

however, it remained lower than values registered in 2019 because economic activities still remained under control; in addition, schools and universities remained closed.

\section{Ozone monthly concentration}

The average monthly $\mathrm{O}_{3}$ concentration and standard deviation in 2019 ranged from $20 \pm 15 \mu \mathrm{g} \mathrm{m}^{-3}$ in Copacabana to $46 \pm 34 \mu \mathrm{g} \mathrm{m}^{-3}$ in Bangu; in 2020, it ranged from
$22 \pm 15 \mu \mathrm{g} \mathrm{m}^{-3}$ in Copacabana to $63 \pm 35 \mu \mathrm{g} \mathrm{m}^{-3}$ in Bangu. Considering the average concentrations obtained between March and September of 2020, with the exception of Bangu station, other monitoring presented an increase up to $93 \%$ in $\mathrm{O}_{3}$ concentration, compared to the same months of 2019. The average concentration in 2020 is $73 \%$ below the Brazilian standard $\left(140 \mathrm{\mu g} \mathrm{m}^{-3}\right)$, while in 2019 it was $78 \%$ lower.

Ozone concentrations registered in Campo Grande and Copacabana since April 2020 were up to $85 \%$ higher than the 
Table 3 Results of the comparison between pairs of months (2019 vs 2020) when no statistical variations were observed in the concentration of the pollutants

\begin{tabular}{|c|c|c|c|c|c|c|}
\hline \multirow[t]{2}{*}{ Station } & \multicolumn{2}{|l|}{$\mathrm{CO}$} & \multicolumn{2}{|l|}{$\mathrm{O}_{3}$} & \multicolumn{2}{|l|}{$\mathrm{PM}_{10}$} \\
\hline & $\begin{array}{l}\text { Pairs of months } \\
\text { (2019 vs 2020) }\end{array}$ & $p$-value & $\begin{array}{l}\text { Pairs of months } \\
\text { (2019 vs 2020) }\end{array}$ & $p$-value & $\begin{array}{l}\text { Pairs of months } \\
\text { (2019 vs 2020) }\end{array}$ & $p$-value \\
\hline Bangu & - & - & $\begin{array}{l}\text { March } \\
\text { April } \\
\text { August }\end{array}$ & $\begin{array}{l}0.312 \\
0.620 \\
0.082\end{array}$ & $\begin{array}{l}\text { August } \\
\text { September }\end{array}$ & $\begin{array}{l}0.561 \\
0.766\end{array}$ \\
\hline Campo Grande & - & - & $\begin{array}{l}\text { July } \\
\text { August }\end{array}$ & $\begin{array}{l}0.927 \\
0.083\end{array}$ & April & 0.927 \\
\hline Centro & $\begin{array}{l}\text { April } \\
\text { September }\end{array}$ & $\begin{array}{l}0.317 \\
0.609\end{array}$ & - & - & June & 0.688 \\
\hline Copacabana & June & 0.133 & - & - & $\begin{array}{l}\text { March } \\
\text { April } \\
\text { June }\end{array}$ & $\begin{array}{l}0.806 \\
0.072 \\
0.133\end{array}$ \\
\hline Tijuca & - & - & $\begin{array}{l}\text { March } \\
\text { April }\end{array}$ & $\begin{array}{l}0.169 \\
0.407\end{array}$ & - & - \\
\hline
\end{tabular}

values registered in March 2020. Tijuca presented concentrations 16-86\% higher since May 2020. In Centro, $\mathrm{O}_{3}$ concentrations registered in April and May were 15-20\% higher than values obtained in March, but in June and August they decreased 14\%, in relation to March and increased again in September (23\%). In Bangu, this pollutant presented a random profile, increase in April, decrease until June, and again increase until September.

In comparison with average concentrations obtained in 2019, statistical differences were observed in Centro and Copacabana in all months, which presented lower concentrations for the entire period. Both regions have undergone drastic routine changes after lockdown decrees; even after opening measures, they did not return to the same routine observed before the pandemic, mainly because most schools opted to keep distance learning and companies choose to continue with the home office or returned to face-to-face activities on a rotating basis. Those changes in routine activities contributed to the decrease in atmospheric pollutants that participate in $\mathrm{O}_{3}$ formation. As observed in other cities around the world, the decrease in some pollutants, as NOx and VOC, induced the increase in $\mathrm{O}_{3}$ concentration.

The Bangu station presented a different behavior, with lower $\mathrm{O}_{3}$ concentration during lockdown. At this station, higher $\mathrm{NO}, \mathrm{NO}_{2}$, and $\mathrm{NOx}$ concentration was recorded in 2020, mainly during the lockdown period, in comparison with the same period of 2019. $\mathrm{As}_{3}$ formation at this region is favored in low NOx levels, during lockdown the increase in $\mathrm{NOx}$ concentration conducted to lower $\mathrm{O}_{3}$ concentration. According to Dantas et al. (2020), since April 6, a reduction in $\mathrm{O}_{3}$ concentrations was recorded which was also favored by less rainfall and lower SR.

\section{Particulate matter monthly concentration}

The average monthly $\mathrm{PM}_{10}$ concentration and standard deviation in 2020 ranged from $13 \pm 10 \mu \mathrm{g} \mathrm{m}^{-3}$ in Centro to
$74 \pm 23 \mu \mathrm{g} \mathrm{m}^{-3}$ in Copacabana, while in 2019, it ranged from $22 \pm 11 \mu \mathrm{g} \mathrm{m}^{-3}$ in Bangu to $57 \pm 22 \mu \mathrm{g} \mathrm{m}^{-3}$ in Copacabana. $\mathrm{PM}_{10}$ concentration profiles for the 2 years were similar. It was the pollutants that showed less concentration variation. The average concentration in 2020 is $70 \%$ below the Brazilian standard, while in 2019 it was $69 \%$ lower.

A question that should be pointed out is that the absolute value of rainfall recorded in 2019 was higher than that in 2020. Some months of 2020 that presented $\mathrm{PM}_{10}$ average concentration with no statistical difference in relation to the previous years recorded less rainfall volume in 2019. Then, in 2019, the rainfall contributed to particle removal, decreasing $\mathrm{PM}_{10}$ concentration. In 2020 , the less rainfall volume was compensated by the decrease in emission caused by routine changes. Thus, even with decrease in $\mathrm{PM}_{10}$ emission in 2020, the average concentration remained similar with that of the previous years. The same behavior of rainfall was also observed by Rudke et al. (2021) in a study conducted in the metropolitan area of São Paulo.

Bangu and Campo Grande presented $\mathrm{PM}_{10}$ concentration in March and April 2-15\% higher than that in the same months of 2019. The other three monitoring stations presented concentrations up to $48 \%$ lower between March and May, compared to the same months of 2019. In June, when economic activities returned partially, a 2-13\% increase was registered in relation to the same month of the previous year which may be attributed to differences on rainfall profile of both years.

Between March and September 2020, the $\mathrm{PM}_{10}$ concentration increased over the months. The main increase was observed in Centro in June and July, when a concentration $130 \%$ higher than that in March was verified. As the economic opening started in June, it was the month when the highest increased concentration was observed for most monitoring stations. Only Tijuca presented the highest concentration in September. 


\section{$\mathrm{CO}, \mathrm{O}_{3}$, and $\mathrm{PM} \mathrm{M}_{10}$ diurnal and weekly cycle}

Pollutant diurnal cycles in 2019 and 2020 were evaluated through the hourly average concentration presented in Figs. 5, 6, and 7. $\mathrm{CO}$ and $\mathrm{PM}_{10}$ concentration diurnal cycles obtained in 2020 were below the values obtained in $2019 . \mathrm{O}_{3}$ concentration diurnal cycles obtained in 2020 presented an opposite behavior because the average concentration in 2020 was higher than that in 2019. However, pollutant concentrations varied from 2019 to 2020; the peak of concentration in 2020 happened at the same time as in 2019 for the three pollutants. Only Bangu presented in 2020 an $\mathrm{O}_{3}$ diurnal cycle below the values obtained in 2019 and $\mathrm{PM}_{10}$ diurnal cycle higher than that in 2019.

The careful examination of each pollutant diurnal cycle shows that the hourly $\mathrm{CO}$ concentration profile was similar to the $\mathrm{PM}_{10}$ profile, with peak concentration in the morning. After the concentration decreases during the afternoon, another peak appears in the evening. The same hourly concentration profile was observed in 2020 , but due to the lower concentrations obtained that year, the variations in concentrations between morning and night were smaller, mainly in Copacabana and Tijuca. This concentration profile is characteristic of urban regions because it varies together with the change in the vehicle flow in the monitored region. The peak of concentration occurs at different times in each of the stations, but this concentration profile is following the times of entry and exit from school, commerce, and industries. The highest concentrations are observed in the morning when there is a large flow of people moving around the city at the same time. Due to the greater variation in the time for returning home, the concentrations at the end of the day are lower than those in the morning.

Higher $\mathrm{O}_{3}$ concentration occurs around noon due to greater SR. In both years, the $\mathrm{O}_{3}$ concentration peak occurred between 1:30 pm and 3:30 pm in all monitoring stations. Bangu presented higher concentrations in 2019, Tijuca presented similar concentrations in both years, and Campo Grande, Centro, and Copacabana presented higher $\mathrm{O}_{3}$ concentrations in 2020. The lower concentrations observed in 2020 may be related to variations in the concentrations of other pollutants that participate in the mechanisms of formation and degradation of the $\mathrm{O}_{3}$ molecule.

$\mathrm{CO}$ weekly cycles obtained in 2020 for all monitoring stations were very similar, while in 2019 they presented different levels of concentrations. As expected, weekday average concentrations were more similar to weekend average concentration. Meanwhile, a higher concentration was observed during weekend than in weekdays, which reflects that some activities that are developed during weekends continued during 2020. $\mathrm{PM}_{10}$ weekly cycles present lower concentration during weekends in the 2 years, and as expected, the variation over the week was lower in 2020 than that in 2019.
However, rainfall profile for 2019 and 2020 was different, which exerts huge influence in $\mathrm{PM}_{10}$ concentration.

$\mathrm{O}_{3}$ week cycles were very similar for all monitoring stations. The diurnal cycle in 2019 shows that weekends present higher concentrations than weekdays. In 2020, the difference between weekdays and weekends was lower than that in the previous year. Besides that, weekends in 2019 and 2020 presented lower differences in concentrations.

As in 2020 a decrease on pollutant emission occurred, it was expected that diurnal cycles would present lower levels. Despite the decrease in traffic, the main pollutant source during the first months, corroborated by mobility data, some essential services demanded workers who went to work in the morning and came home in the evening. Thus, peak concentration time remained, in comparison with the previous year. The weekly concentration presented a random variability during weekdays for both years; however, in 2020 this variation was lower, which implies that the behaviors of source emission were similar from Mondays to Tuesdays. $\mathrm{CO}$ and $\mathrm{PM}_{10}$ presented an increase on Friday and Saturday which is justified by higher mobility on these days. On the opposite way, $\mathrm{O}_{3}$ presented higher levels on Monday, when the lowest mobility was recorded, since less primary pollutant emission leads to lower $\mathrm{O}_{3}$ concentration.

\section{Time average with satellite data}

An important factor that influences air quality is atmospheric transport which may carry pollutants from one region to others, which could contribute to the concentrations recorded at monitoring sites. Since the Brazilian atmospheric monitoring network is reduced, satellite data helps in better understanding. Figure 9 shows the time average map for $\mathrm{CO}$ and aerosol obtained from Giovanni/NASA. In the region of Rio de Janeiro, a slight increase in CO concentrations occurred but was more significant for aerosol. An interesting observation is the huge increase of $\mathrm{CO}$ and aerosol in the Amazon Region that also extends to the Pantanal. July to September is the period when many fires are registered in the Amazon region. Especially in 2020, Pantanal burned during the same period. It is well known that fires emit $\mathrm{CO}$ and particulate matter, which explains a large amount of these pollutants in Amazon and Pantanal.

Time average maps for the three periods considered indicate that $\mathrm{CO}$ and aerosol increased over time, as surface data demonstrated. Currently, to economic opening which contributed to increase in mobility, and consequently in pollutant emission, fires recorded at Amazon and Pantanal may transport pollutants to southeast Brazil, contributing to pollutant increasing. Rudke et al. (2021) also considered that fires contributed to air pollution in São Paulo in the months that followed stricter isolation measures. 
March - April 2020

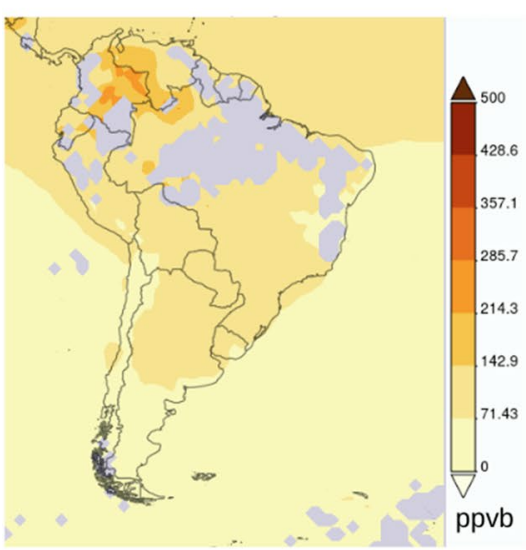

May - June 2020

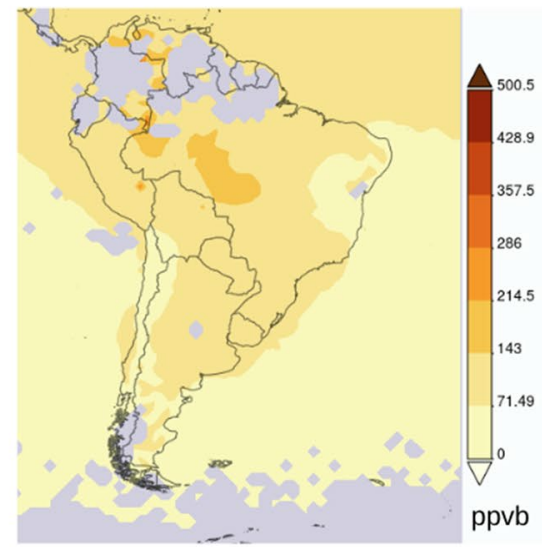

\section{July - September 2020}

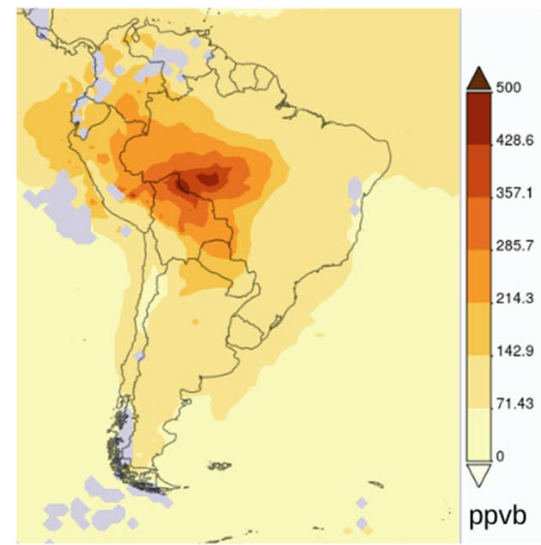

Multispectral CO Surface Mixing Ratio (Daytime/Descending)
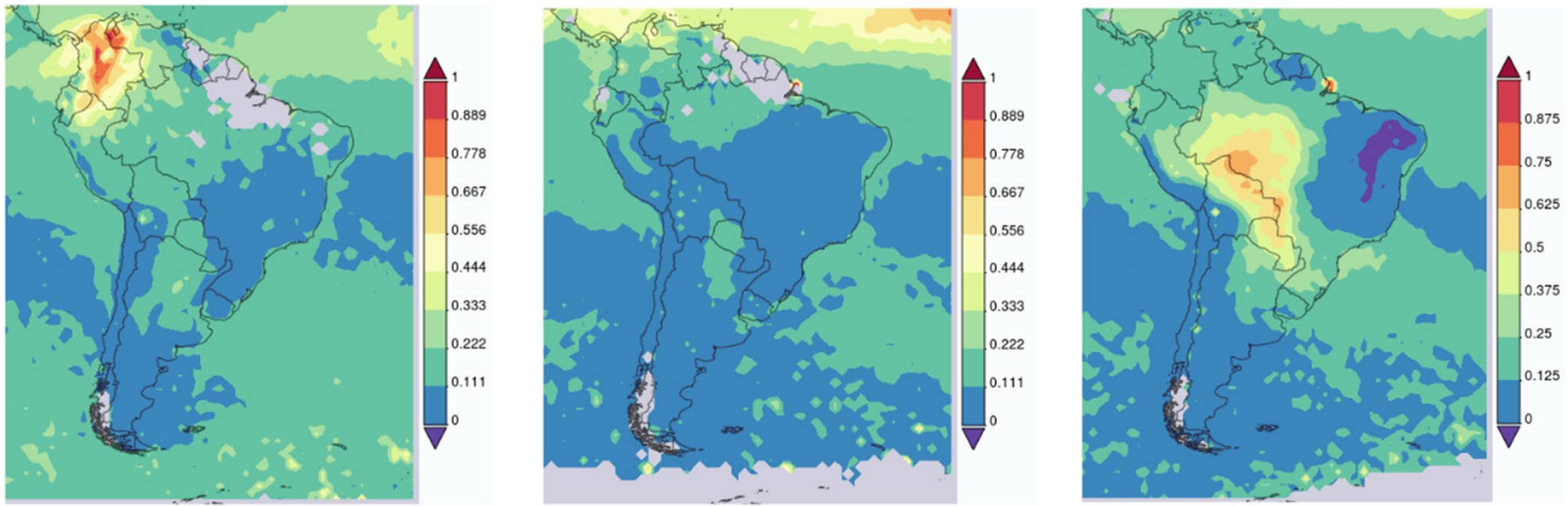

Combined Dark Target and Deep Blue AOD at 0.55 micron for land and ocean

Fig. 9 Time average map plotted with satellite data obtained by Giovanni/NASA for CO and aerosol from March to September 2020. Source: https://giovanni.gsfc.nasa.gov

\section{Conclusions}

The assessment of atmospheric pollution is a complex task, one that depends on several factors, including pollutant emissions, meteorological conditions, and interaction of them, mainly to secondary pollutant formation. Even if it is possible to control the emission sources, the number of atmospheric processes involved and the dependency on meteorology make the air quality highly difficult to control.

The period considered in this air quality assessment was marked by striking changes in urban routine, which represented a decrease of mobility of about $90 \%$, then the city presented a new emission profile. Primary pollutant concentrations ( $\mathrm{PM}_{10}$ and $\left.\mathrm{CO}\right)$ were reduced as a consequence of emission source reduction during the lockdown; however, secondary pollutants $\left(\mathrm{O}_{3}\right)$ increased as a result of several changes in atmospheric conditions. Around the world, this behavior was observed after lockdown measures, highlighting the increase in $\mathrm{O}_{3}$ concentration responding to the reduction in pollutant concentration that participates in tropospheric ozone formation.

Rio de Janeiro is one of the major Brazilian metropolises; therefore, vehicle emission is considered the main atmospheric pollutant source. Thus, the huge traffic reduction, as a consequence of mobility decrease, after lockdown decree induced a significant $\mathrm{CO}$ concentration reduction, since fossil combustion is its principal source. The same notable reduction was not observed for $\mathrm{PM}_{10}$ because of the differences in rainfall profiles between the 2 years. Rainfall volumes recorded in Campo Grande, Centro, and Copacabana in $2019(0.13,0.13$, and $0.20 \mathrm{~mm})$ were higher than those in $2020(0.08,0.07$, and $0.10 \mathrm{~mm})$; thus, even with emission reduction in 2020 caused by routine changes, $\mathrm{PM}_{10}$ concentration varied little. As characteristic 
of urban areas, daily concentration peak for both pollutants remained at the same time of 2019 even with lower values in 2020. As expected, and observed around the world, $\mathrm{O}_{3}$ concentrations increased in urban areas where the $\mathrm{O}_{3}$ production is VOC limited. The $\mathrm{O}_{3}$ diurnal cycle presented a peak of concentrations at the same time as the previous year, which is related to the SR intensity that enhances the tropospheric $\mathrm{O}_{3}$ formation by photochemical processes.

Once the isolation measures removed a lot of people from the street and the mobility reduced significantly during the period evaluated, pollutant concentrations recorded for weekdays became similar to the values that are usually recorded for the weekend. In other words, the lockdown period, mainly in the first months, was similar to a very long weekend period, especially during the first month. Following an increase in mobility since June 2020, pollutant concentrations also rose. At this time, people started to come back to some activities while the government scheduled an economic opening. Satellite data also show this behavior, even though they also indicate a possible contribution of fires at Amazon and Pantanal in CO and PM concentrations in southeast Brazil.

Air pollution responds quickly to changes in factors that participate in the atmospheric process. While the emission sources were reduced during the isolation period, a reduction in $\mathrm{CO}$ and $\mathrm{PM}_{10}$ was observed, but the easing measures started were followed by an increase in these pollutants. As $\mathrm{O}_{3}$ depends on other pollutant concentrations, it presented an opposite behavior; however, the CONAMA standards for $\mathrm{O}_{3}$ were not exceeded. The partial maintenance of home office and distance learning contributed to the concentrations recorded after the isolation easing which remain lower than those in 2019. Perhaps, this could be an adequate alternative to control air pollution when the pandemic issue is resolved.

Supplementary Information The online version contains supplementary material available at https://doi.org/10.1007/s11869-021-01127-2.

Acknowledgements The authors thank CNPq and FAPERJ for research grants and financial support and Municipal Department of the Environment for providing air quality data obtained in their monitoring network. This article and the research behind it are a direct contribution to the research themes of the Klimapolis Laboratory (klimapolis.net). Networking and coordination activities of the Klimapolis Laboratory are funded by the German Federal Ministry of Education and Research (BMBF).

Author contribution All the authors contributed to the study conception and design. Data collection and organization were performed by KB. Data analysis was performed by KB, ADF, WFCR, and AD. The first drafts of the manuscript were written by KB, ADF, and EPSJ and all the authors commented on previous versions of the manuscript. AG, $\mathrm{AD}$, and $\mathrm{BBF}$ made critical reviews. All the authors read and approved the final manuscript.

Funding This study was financed in part by the Coordenação de Aperfeiçoamento de Pessoal de Nível Superior - Brasil (CAPES) Finance Code 001, Conselho Nacional de Pesquisa - Brasil (CNPq), and Fundação Carlos Chagas Filho de Amparo à Pesquisa do Estado do Rio de Janeiro (FAPERJ).

Data availability The datasets used and/or analyzed during the current study are available from the corresponding author on reasonable request.

\section{Declarations}

Ethical approval and consent to participate Not applicable.

Consent for publication Not applicable.

Competing interests The authors declare no competing interests.

\section{References}

Ali MU, Liu G, Yousaf B et al (2019) A systematic review on global pollution status of particulate matter-associated potential toxic elements and health perspectives in urban environment. Springer, Netherlands

Bao R, Zhang A (2020) Does lockdown reduce air pollution? Evidence from 44 cities in northern China. Sci Total Environ 731:139052. https://doi.org/10.1016/j.scitotenv.2020.139052

Bolaño-Ortiz TR, Pascual-Flores RM, Puliafito SE et al (2020) Spread of COVID-19, meteorological conditions and air quality in the city of Buenos Aires, Argentina: two facets observed during its pandemic lockdown. Atmosphere (basel) 11:1-23. https://doi.org/ $10.3390 /$ atmos 11101045

Brandao R, Foroutan H (2021) Air quality in Southeast Brazil during COVID-19 lockdown: a combined satellite and ground-based data analysis. Atmosphere (Basel) 12https://doi.org/10.3390/atmos 12050583

Camargo-Caicedo Y, Mantilla-Romo LC, Bolaño-Ortiz TR (2021) Emissions reduction of greenhouse gases, ozone precursors, aerosols and acidifying gases from road transportation during the COVID-19 lockdown in Colombia. Appl Sci 11:1-18. https://doi. org/10.3390/app11041458

Chapin C, Roy S (2021) A spatial web application to explore the interactions between human mobility, government policies, and COVID-19 cases. J Geovisualization Spat Anal 5https://doi.org/ 10.1007/s41651-021-00081-y

Collivignarelli MC, Abbà A, Bertanza G et al (2020) Lockdown for CoViD-2019 in Milan: what are the effects on air quality? Sci Total Environ 732:1-9. https://doi.org/10.1016/j.scitotenv.2020. 139280

CONAMA (2018) Resolução nº 491/18 de 18 de novembro de 2018. Brasil

Croda J, Oliveira WK de, Frutuoso RL et al (2020) Covid-19 in Brazil: Advantages of a socialized unified health system and preparation to contain cases. Rev Soc Bras Med Trop 53:2-7. https://doi.org/ 10.1590/0037-8682-0167-2020

Crokidakis N (2020) COVID-19 spreading in Rio de Janeiro, Brazil: do the policies of social isolation really work? Chaos. Solitons and Fractals 136:109930. https://doi.org/10.1016/j.chaos.2020.109930

Dantas G, Siciliano B, França BB et al (2020) The impact of COVID19 partial lockdown on the air quality of the city of Rio de Janeiro. Brazil Sci Total Environ 729:139085. https://doi.org/10.1016/j. scitotenv.2020.139085

De La Cruz ARH, Dionisio Calderon ER, França BB et al (2019) Evaluation of the impact of the Rio 2016 Olympic Games on 
air quality in the city of Rio de Janeiro, Brazil. Atmos Environ 203:206-215. https://doi.org/10.1016/j.atmosenv.2019.02.007

Debone D, da Costa MV, Miraglia SGEK (2020) 90 days of COVID-19 social distancing and its impacts on air quality and health in Sao Paulo, Brazil. Sustain 12:1-16. https://doi.org/10.3390/SU121 87440

Detran (2020) Detran Estatísticas. http://www.detran.rj.gov.br/_estat isticas.veiculos/07.asp?menuzinho=07.asp. Acessed July 2021

Filonchyk M, Peterson M (2020) Air quality changes in Shanghai, China, and the surrounding urban agglomeration during the COVID-19 lockdown. J Geovisualization Spat Anal 4https://doi. org/10.1007/s41651-020-00064-5

Gaubert B, Bouarar I, Doumbia T et al (2021) Global changes in secondary atmospheric pollutants during the 2020 COVID-19 pandemic. J Geophys Res Atmos. https://doi.org/10.1029/2020j d034213

Geraldino CGP, Arbilla G, da Silva CM, et al (2020) Understanding high tropospheric ozone episodes in Bangu, Rio de Janeiro, Brazil. Environ Monit Assess 192https://doi.org/10.1007/ s10661-020-8119-3

Geraldino CGP, Martins EM, da Silva CM, Arbilla G (2017) An analytical investigation of ozone episodes in Bangu, Rio de Janeiro. Bull Environ Contam Toxicol 98:632-637. https://doi.org/10. 1007/s00128-017-2041-6

Gioda A, Oliveira RCG, Cunha CL, Corrêa SM (2018) Understanding ozone formation at two islands of Rio de Janeiro, Brazil. Atmos Pollut Res 9:278-288. https://doi.org/10.1016/j.apr.2017.10.003

Girdhar A, Kapur H, Kumar V, et al (2020) Effect of COVID-19 outbreak on urban health and environment. Air Qual Atmos Heal 389-397https://doi.org/10.1007/s11869-020-00944-1

IBGE (2020) Cidades Brasileiras. https://cidades.ibge.gov.br/brasil/rj/ rio-de-janeiro/panorama. Acessed July 2021

Kim MJ (2019) Changes in the relationship between particulate matter and surface temperature in Seoul from 2002-2017. Atmosphere (Basel) 10. https://doi.org/10.3390/atmos10050238

Le T, Wang Y, Liu L et al (2020) Unexpected air pollution with marked emission reductions during the COVID-19 outbreak in China. Science (80) 369:702-706. https://doi.org/10.1126/science.abb7431

Li Y, Chen Q, Zhao H et al (2015) Variations in pm10, pm2.5 and pm1.0 in an urban area of the Sichuan basin and their relation to meteorological factors. Atmosphere (basel) 6:150-163. https:// doi.org/10.3390/atmos6010150

Ministério da Saúde (2021) Painel Coronavírus. https://covid.saude. gov.br. Accessed 3 May 2021

Miranda RM, de Andrade M, F, Fornaro A, et al (2012) Urban air pollution: a representative survey of PM 2.5 mass concentrations in six Brazilian cities. Air Qual Atmos Heal 5:63-77. https://doi.org/ 10.1007/s11869-010-0124-1

MMA (2019) Guia Técnico para o Monitoramento e Avaliação da Qualidade Do Ar

Nakada LYK, Urban RC (2020) COVID-19 pandemic: impacts on the air quality during the partial lockdown in São Paulo state. Brazil Sci Total Environ 730:139087. https://doi.org/10.1016/j.scitotenv. 2020.139087

Nishanth T, Praseed KM, Kumar MKS, Valsaraj KT (2014) Influence of ozone precursors and PM10 on the variation of surface $\mathrm{O} 3$ over Kannur, India. Atmos Res 138:112-124. https://doi.org/10.1016/j. atmosres.2013.10.022
Prefeitura do Rio de Janeiro (2021) Painel Rio COVID-19. 24

Rojas JP, Urdanivia FR, Garay RA et al (2021) Effects of COVID-19 pandemic control measures on air pollution in Lima metropolitan area, Peru in South America. Air Qual Atmos Heal 14:925-933. https://doi.org/10.1007/s11869-021-00990-3

Rudke AP, Martins JA, de Almeida DS, et al (2021) How mobility restrictions policy and atmospheric conditions impacted air quality in the State of São Paulo during the COVID-19 outbreak. Environ Res 198https://doi.org/10.1016/j.envres.2021.111255

Saadat S, Rawtani D, Hussain CM (2020) Environmental perspective of COVID-19. Sci Total Environ 728:138870. https://doi.org/10. 1016/j.scitotenv.2020.138870

Sarfraz M, Shehzad K, Farid A (2020) Gauging the air quality of New York: a non-linear nexus between COVID-19 and nitrogen dioxide emission. Air Qual Atmos Heal 13:1135-1145. https://doi.org/10. 1007/s11869-020-00870-2

Siciliano B, Carvalho G, da Silva CM, Arbilla G (2020) The impact of COVID-19 partial lockdown on primary pollutant concentrations in the atmosphere of Rio de Janeiro and São Paulo Megacities (Brazil). Bull Environ Contam Toxicol. https://doi.org/10.1007/ s00128-020-02907-9

Tobías A, Carnerero C, Reche C et al (2020) Changes in air quality during the lockdown in Barcelona (Spain) one month into the SARS-CoV-2 epidemic. Sci Total Environ 726:138540. https:// doi.org/10.1016/j.scitotenv.2020.138540

Venter ZS, Aunan K, Chowdhury S, Lelieveld J (2020) COVID-19 lockdowns cause global air pollution declines. Proc Natl Acad Sci U S A 117:18984-18990. https://doi.org/10.1073/pnas.20068 53117

Voulgarakis A, Telford PJ, Aghedo AM et al (2011) Global multiyear O3-CO correlation patterns from models and TES satellite observations. Atmos Chem Phys 11:5819-5838. https://doi.org/ 10.5194/acp-11-5819-2011

World Health Organization (2020) WHO Director-General's opening remarks at the media briefing on COVID-19 - 11 March 2020. In: WHO. https://www.who.int/dg/speeches/detail/ who-director-general-s-opening-remarks-at-the-media-brief ing-on-covid-19---11-march-2020

Zambrano-Monserrate MA, Ruano MA (2020) Has air quality improved in Ecuador during the COVID-19 pandemic? A parametric analysis. Air Qual Atmos Heal 13:929-938. https://doi.org/ 10.1007/s11869-020-00866-y

Zangari S, Hill DT, Charette AT, Mirowsky JE (2020) Since January 2020 Elsevier has created a COVID-19 resource centre with free information in English and Mandarin on the novel coronavirus COVID- 19. The COVID-19 resource centre is hosted on Elsevier Connect, the company' s public news and information

Publisher's note Springer Nature remains neutral with regard to jurisdictional claims in published maps and institutional affiliations. 